Maurice A. Deane School of Law at Hofstra University Scholarly Commons at Hofstra Law

Hofstra Law Faculty Scholarship

2008

\title{
Finally a Guidebook for New York's Impenetrable Election System
}

Eric Lane

Maurice A. Deane School of Law at Hofstra University

Follow this and additional works at: https://scholarlycommons.law.hofstra.edu/faculty_scholarship

\section{Recommended Citation}

Eric Lane, Finally a Guidebook for New York's Impenetrable Election System, 7 ELJ 271 (2008)

Available at: https://scholarlycommons.law.hofstra.edu/faculty_scholarship/386

This Book Review is brought to you for free and open access by Scholarly Commons at Hofstra Law. It has been accepted for inclusion in Hofstra Law Faculty Scholarship by an authorized administrator of Scholarly Commons at Hofstra Law. For more information, please contact lawcls@hofstra.edu. 


\title{
Book Review
}

\section{Finally A Guidebook for New York's Impenetrable Election System}

\author{
ERIC LANE
}

Jerry H. Goldfeder, Goldfeder's Modern Election Law. New York: New York Legal Publishing, 446 pp., \$125 (paperback).

\begin{abstract}
A S SOMEONE WHO has occasionally mustered the courage to take small steps into the impenetrable landscape that is New York's election law, I can attest to the overwhelming loss of direction that accompanies the effort, and the anxiety and the fear that follow, as one tries desperately to return to safety. And wise the retreat, because, for the average adventurer, courage and fortitude are not sufficient virtues for a successful passage through this dark place. "A maze, whose corridors are compounded by hurdles, to be negotiated by only the wariest of candidates" is how one New York appellate court once described it. ${ }^{1}$ And, in the more mundane language of government commissions, the New York State Commission on Government Integrity concluded: "The procedural vagaries of the law are indeed overwhelming both in their complexity and their rigidity" and its collective requirements "unreasonably restrict access to the ballot and thereby undermine the legitimacy of the primary process as a means of selecting nominees who command the support of party members, not just the party leaders."2
\end{abstract}

Eric Lane is a Professor of Law, Hofstra University School of Law, Senior Fellow Brennan Center for Justice, and coauthor of Genius of America: How the Constitution Saved Our Country and Why it Can Again (Bloomsbury USA, 2007).
New York's draconian restrictions on ballot access and competition should surprise no one. As one of her most important sons, Alexander Hamilton, told his colleagues at the Constitutional Convention: "Men love power . . . Give all the power to the many, they will oppress the few. Give all the power to the few, they will oppress the many."3 And politicians in New York have not let Hamilton down. In modern days the state government is run almost exclusively by a three-men-in-the-room troika of the governor, majority leader of the senate, and speaker of the Assembly. This arrangement has caused its government to be judged among the most dysfunctional in America by the Brennan Center for Justice. ${ }^{4}$ And the selection of its elected judges is almost exclusively dominated by its political bosses, making competition for judicial nominations almost an accident. ${ }^{5}$

Despite the claims that New York's statutory regimen is intended to protect against fraud, years of resistance to repairing obvious problems (except for some minor changes in 1993

\footnotetext{
${ }^{1}$ Erazo v. Lipper, 112 A.D.2d 880, 880 (1985).

2 JerRy H. GoldFEDER, MODERN Election LaW 31 (2007).

3 James Madison, Notes of Debates in the Federal ConVENTION, 131-35 (1987).

${ }^{4}$ Jeremy M. Creeland and Laura M. Moulton, The New York State Legislative Process: An Evaluation and Blueprint for Reform (2004).

${ }^{5}$ See New York State Bd. of Elections v. Lopez Torres, 128 S.Ct. 791 (2008) (holding New York's system constitutional but explaining how its political bosses dominate the selection of judges).
} 
and some slightly better ones in 1996) have demonstrated its current virtues are the protection of incumbents and established political parties. No witness to the endless petition challenges and subsequent litigation can argue otherwise. Whatever its initial purpose, what the system continues to accomplish is, as one court put it, "the disenfranchisement of tens of thousands of citizens who would support candidates not possessed of the resources to engage the assistance required to negotiate [it]." 6

Entering this morass to provide guidance is Jerry Goldfeder. Goldfeder is now the Special Counsel to the New York State Attorney General with a public integrity portfolio. But he has for a long time been an election law practitioner and educator. He has also stood for office. His counsel has been sought by numerous candidates, bar associations, and judicial groups. He has also written on the topic and taught election law courses. So for those of us who keep an eye on New York election law developments, anticipation of a book from such a thoughtful and seasoned player was highly anticipated. Goldfeder does not disappoint.

In Modern Election Law, his guidebook to New York's election law, Goldfeder leads us from the starting line safely to the end. He does so with clarity and precision. Starting with the daunting task of getting on the ballot and ending with the difficult decision of whether or not to challenge election results, Goldfeder provides a map of the election system and clear directions on how to negotiate its many obstacles, among them regulations governing eligibility, residency, the petition, the committee to fill vacancies, petitioning to gain ballot access, staying on the ballot, election day, money, political parties, and -believe it or not-many more topics. The book also includes a series of election law forms and New York's election statutes. And ever the teacher, Goldfeder gives election law lawyers a test through a number of hypothetical ethical questions, which are very thoughtful and practical. Fortunately, unlike law school texts, he also provides the answers for the students.

Goldfeder presents his material with considerable detail, consistent with the very detailed enforcement of the law required by New York's courts. Hence, with regard to petition carriers and subscribers, we learn that notaries and commissioners of deeds can carry witness petition signatures but that their subscribing statements "require that these petition carriers ask the signers to swear or affirm that they are actually the person whose name they sign." No actual oath must be administered, "but some verbal exchange attesting to authenticity of the action is." ${ }^{\prime 7}$

His coverage of election day is so complete as to be almost overwhelming. The titles alone make the point: Polling site coordinator, poll clerk, interpreter, additional personnel, police, hours, materials needed, and on and on.

Beyond the detail, the book is filled with tips for the unwary. Again using the petition process as an example, Goldfeder warns a candidate to keep "a healthy distance from her petitions," ${ }^{8}$ although nothing in the law outlaws such participation. The problems according to Goldfeder are twofold: first, if the petition is ever litigated, the candidate will no doubt become a witness in the case, wasting precious campaign time. Second, in the event any fraud is found in the petition process, the candidate or his family's involvement might suggest to the court some proximity between the candidate and the fraud putting at risk the entire petitioning effort and not just one or more individual petitions.

The book also addresses some broader campaign issues such as financing. New York (and this should cause no surprise) has one of the nation's most loosely regulated private campaign funding systems. Of course constitutionally a campaign can spend as much as it wants and candidates can contribute as much as they want to their own campaigns. But beyond that in New York an individual can contribute up to a total of $\$ 150,000$ to candidates in a calendar year, and up to $\$ 55,000$ to a candidate for governor in a gubernatorial election cycle, assuming there is a primary. There are pretty rigorous reporting requirements, but little meaningful enforcement. The courts have, to a large extent, made it clear that enforcement is within

\footnotetext{
${ }^{6}$ Erazo v. Lipper, 112 A.D.2d 880, 880 (1985).

7 GOLDFEDER, supra, note 2 , at 26.

${ }^{8}$ Id. at 40 .
} 
the province of the State Election Board, which has neither the resources nor apparently the authority or will for meaningful action. "When it is all said and done," Goldfeder informs, "it appear that New York's campaign finance laws are rarely, if ever, enforced." 9

One small discussion in the book does not deserve the same high level of praise. During his discussion of money Goldfeder turns his (here overly) critical eye to New York City's highly successful and praised publicly funded campaign finance system. He characterizes it as "routinely criticized for over enforcement."10 For the most part that criticism is generated by campaigns whose readings of the statutory scheme have been rejected by New York City's Campaign Finance Board. New York City politics is a brutal competition and its players frequently try to game (find loopholes in) the system for their own advantage. To protect public money, competitive opportunities, and the integrity of the system, the Board has had to be very wary of campaign conduct and very rigorous in the enforcement of its rules. While it has erred sometimes in its rigor, any other approach would assure that the ever present candidate self-interest would throw the system into chaos.

Meaningful contributions to our democracy are most often the product of small efforts to make the system more inclusive and fair. Modern Election Law is one such effort. Through its instruction more people will have more opportunities to participate in New York's political process, a worthy goal for any book.

Address correspondence to: Eric Lane

Hofstra University School of Law 121 Hofstra University Hempstead, NY 11549-1210

E-mail: Eric.Lane@hofstra.edu

${ }^{9}$ GolDFEDER, supra note 2, at 103.

${ }^{10} \mathrm{Id}$. at 102. 